\title{
Behaviour of Silica and Florisil as Solid Supports in the Removal Process of As(V) from Aqueous Solutions
}

\author{
Andreea Gabor, Corneliu Mircea Davidescu, Adina Negrea, \\ Mihaela Ciopec, and Lavinia Lupa \\ Faculty of Industrial Chemistry and Environmental Engineering, University Politehnica of Timişoara, \\ Boulevard Vasile Pârvan No. 6, 300223 Timişoara, Romania \\ Correspondence should be addressed to Lavinia Lupa; lavinia.lupa@upt.ro
}

Received 20 November 2014; Revised 4 January 2015; Accepted 4 January 2015

Academic Editor: Joseph J. Pesek

Copyright (c) 2015 Andreea Gabor et al. This is an open access article distributed under the Creative Commons Attribution License, which permits unrestricted use, distribution, and reproduction in any medium, provided the original work is properly cited.

In this study two solid supports, silica and florisil, were impregnated with crown ether (dibenzo-18-crown-6) and Fe(III) ions and their efficiency was compared in the adsorption process of $\mathrm{As}(\mathrm{V})$ from aqueous solutions. The solid supports were impregnated with crown ether due to their ability to build complexes with positives ions. Fe(III) was used because of As(V) affinity for it. The impregnated solid supports were characterized by energy dispersive X-ray analysis, scanning electron microscopy, Fourier transform infrared spectroscopy, and the specific surface area. The influence of the solid: liquid ratio on the adsorption process, kinetic studies for the pseudo-first-order and pseudo-second-order, and activation energy were studied. Thermodynamic studies as well as equilibrium studies were carried out. The obtained results showed that, from the two considered materials, impregnated silica presents a higher efficiency with a good selectivity, able to remove As(V) from aqueous solutions containing trace concentrations.

\section{Introduction}

It is known that groundwater contains different contaminants. Independently, if the source is natural or anthropogenic, the contaminants have to be eliminated because they represent a threat for human health. One of these contaminants that are worldwide spread is arsenic $[1,2]$. In groundwater, arsenic often appears as inorganic form such as arsenate $\mathrm{As}(\mathrm{V})$ and arsenite $\mathrm{As}(\mathrm{III})$ [3-5]. Because of its toxicity, the World Health Organization (WHO) changed the guidelines from 0.05 to $0.01 \mathrm{mg} / \mathrm{L}$ in 1993 and the United States Environmental Protection Agency from $50 \mu \mathrm{g} / \mathrm{L}$ to $10 \mu \mathrm{g} / \mathrm{L}$ in $2002[3,4]$. Therefore, scientists have the challenge to find different methods to eliminate arsenic from water sources. One of the most efficient technologies to eliminate arsenic from aqueous solutions is the adsorption. The adsorbent used in the adsorption has a big influence on the effectiveness of the process. Silica based adsorbents are known as a good support because they are stabile in acidic conditions and have a high surface area, fast kinetics in the adsorption process, high thermal resistance, and high mass exchange characteristics [6]. Silica particles have been studied worldwide because they have a good adsorption capacity. They can be modified for specific contaminant or species so they become selective and stabile adsorbent [4]. Organized mesoporous silica can be used as a support matrix. Metal oxide can be added onto silica and used for removing a specific pollutant and in catalytic reactions. Organized mesoporous silica has a narrow pore size distribution range and high porosity. Mean pore size, surface area, and porosity can be controlled to a certain extent [7]. Due to their advantages in this paper, a comparative study was made between the adsorbent performance of silica and florisil in the removal process of $\mathrm{As}(\mathrm{V})$ from aqueous solutions. In order to enhance the adsorbent properties of these two solid supports, they were impregnated with crown ether and iron ions. For the impregnation of the extractant onto a solid support, four methods were developed: the dry method (DM), wet method, modifier addition method, and dynamic column method (CM) [8]. Crown ether (dibenzo-18-crown-6) was used due to its ability to form complexes with positive ions. Scientists have used this feature and modified the structure of crown ether to profit from this characteristic. Depending on the size of the ion and on the size of its cavity, crown 
ethers can bind different ions [9-11]. For this reason, it was also loaded with iron ions. Many iron-based adsorbents were developed in the last years [12-15]. Even iron-silica composite was developed $[15,16]$. In many cases these adsorbent materials reported in the literature that data developed higher adsorption capacities in the removal process of $\mathrm{As}(\mathrm{V})$ from aqueous solutions, but unfortunately they are used to remove arsenic from aqueous solution containing concentration like ppm and are not able to absorb arsenic from underground water containing trace concentration $(<100 \mu \mathrm{g} / \mathrm{L})$, the most often situation found in nature $[12-14,17]$. It is useful to encapsulate iron within crown ether that confers favorable hydraulic properties, durability, and mechanical strength. $\mathrm{As}(\mathrm{V})$ and As(III) can be removed by iron-based adsorbents from aqueous solutions $[3,18]$.

In this way, the arsenic selectivity of metal oxides is combined with the durability of a material support [19]. Impregnating the materials with specific affinity positive ions for As and adding specific surface groups for chemisorption can optimize the material removal capacity $[7,20]$.

\section{Materials and Methods}

2.1. Impregnation of the Solid Supports. Silica and florisil were impregnated with crown ether (dibenzo-18-crown-6) and Fe(III) ions using the dry method. Over $1 \mathrm{~g}$ of solid support was added to $0,01 \mathrm{~g}$ of crown ether (Merck, Germany) used as solvent $25 \mathrm{~mL}$ of acetone (VWR Prolabo Chemicals, France). In these solutions, Fe(III) ions were also added in order to obtain a concentration of $400 \mathrm{mg} / \mathrm{L}$ from a standard solution of $1 \mathrm{~g} / \mathrm{L} \mathrm{Fe}\left(\mathrm{NO}_{3}\right)_{3}$ (Merck, Germany) in $0,5 \mathrm{~mol} / \mathrm{L}$ $\mathrm{HNO}_{3}$ solution. The sample was kept in contact for $24 \mathrm{~h}$. After that, it was dried at $323.15 \mathrm{~K}$ for $24 \mathrm{~h}$.

2.2. Characterization of the Obtained Adsorbents. The obtained solid support was characterized by energy dispersive $\mathrm{X}$-ray analysis (EDX) and scanning electron microscopy (SEM), in order to highlight that the impregnation with $\mathrm{Fe}^{\mathrm{III}}$ occurred, using a scanning electron microscopy (SEM) Quanta FEG 250, equipped with energy dispersive X-ray quantifier (EDAX ZAF). For measuring the specific surface area BET Nova 1200 E Quantachrome was used at a temperature of $77 \mathrm{~K}$ with nitrogen $\left(\mathrm{N}_{2}\right)$. The samples were degassed with vacuum for 5 hours at room temperature. The impregnation of the solid supports with crown ether and iron ions was also evidenced by FTIR analysis. The FTIR spectra (KBr pellets) of the obtained adsorbent were recorded on a Shimadzu Prestige-21 FTIR spectrophotometer in the range $4000-400 \mathrm{~cm}^{-1}$.

2.3. Adsorption Experiments. For this experiment, a stock solution of arsenic of $1 \mathrm{~g} / \mathrm{L} \mathrm{As}(\mathrm{V})$ solution (Merck Standard Solutions) was used. Other solutions of $\mathrm{As}(\mathrm{V})$ ions were prepared from the stock solution by appropriate dilution. The experiments were performed at an initial $\mathrm{pH}$ of 7-8. It was adjusted using $\mathrm{NaOH}$ and $\mathrm{HNO}_{3}$ solutions of different concentrations. The $\mathrm{pH}$ was measured with a Knick $\mathrm{pH}-$ Meter 765 Calimatic fitted with a glass electrode which
TABLE 1: BET analysis summary of impregnated silica and florisil.

\begin{tabular}{lccc}
\hline & $\begin{array}{c}\text { Surface area } \\
\left(\mathrm{m}^{2} / \mathrm{g}\right)\end{array}$ & $\begin{array}{c}\text { Pore volume } \\
(\mathrm{cc} / \mathrm{g})\end{array}$ & $\begin{array}{c}\text { Pore width } \\
(\mathrm{nm})\end{array}$ \\
\hline Impregnated silica & 237 & 0.663 & 5.69 \\
Impregnated florisil & 155 & 0.274 & 3.63 \\
\hline
\end{tabular}

had been calibrated using various buffer solutions. First the variation of solid:liquid ratio $(\mathrm{S}: \mathrm{L})$ was studied. 0,1 ; 0,$2 ; 0,3 ; 0,4 ; 0,5 \mathrm{~g}$ of impregnated silica and of impregnated florisil were mixed with $25 \mathrm{~mL}$ solution of arsenic having a concentration of $100 \mu \mathrm{g} / \mathrm{L}$, for one hour. A Julabo SW23 mechanical shaker bath was used at $200 \mathrm{rot} / \mathrm{min}$ and at a temperature of $298 \mathrm{~K}$. The filtrate was collected for As(V) analysis.

To study the effect of the contact time, $0.1 \mathrm{~g}$ of impregnated silica, $0.5 \mathrm{~g}$ of impregnated florisil, and $25 \mathrm{~mL}$ solution of arsenic were shacked for 30, 60, 120, 180, and 240 minutes. This was carried out for three temperatures: 298, 308, and $318 \mathrm{~K}$. The samples were then filtrated and the residual concentration of As $(\mathrm{V})$ was analyzed.

The effect of the initial As $(\mathrm{V})$ concentration $\left(C_{0}=25\right.$, $50,75,100,125$, and $150 \mu \mathrm{g} / \mathrm{L})$ was also studied. The samples were kept in contact for one hour with $25 \mathrm{~mL}$ arsenic solution with different concentrations, keeping the same solid: liquid ratio. The filtrate was collected for As(V) analysis. All As(V) analyses were made using inductively coupled plasma mass spectrometry ICP-MS Bruker Aurora M90.

\section{Results and Discussion}

3.1. Characterization of Silica and Florisil Impregnated with Crown Ether and $\mathrm{Fe}(\mathrm{III})$. From the BET measurements, the specific surface area and total pore volume were determined (Table 1). Figure 1 presents the $\mathrm{N}_{2}$ adsorption and desorption of impregnated florisil and silica. In Figure 1, it can be noted that the silica samples display a higher mesoporous volume than the florisil samples. In case of silica samples, the isotherms are characteristic for isotherms of type IV and a H1 hysteresis loop. Type IV isotherms occur on porous adsorbents possessing pores in the radius range of approximately 15-1000 angstroms (A). The slope increase at higher elevated pressures indicates an increased uptake of adsorbate as the pores are being filled. Type H1 hysteresis loops are typical for adsorbents with well-defined structures and narrow pore size distributions. This type of isotherms presents a hysteresis loop which is specific for mesoporous materials which present a capillary condensation. The increase in the $\mathrm{N}_{2}$ adsorbed volume is higher in the region of 0.7 and 0.9 relative pressure. The macropores volume of silica materials is very limited as shown by the plateau achieved for $\mathrm{N}_{2}$ adsorption isotherms at relative pressure between 0.9 and 1.0. The samples with florisil present a type IV isotherm and a $\mathrm{H} 3$ hysteresis loop. Type $\mathrm{H} 3$ loops are usually given by aggregates of plate-like particles or adsorbents containing slit-shaped pores [7, 21-25].

Table 1 summarizes the physical characteristics of the materials after impregnation and it can be noticed that the impregnated silica presents a higher surface area and porosity 


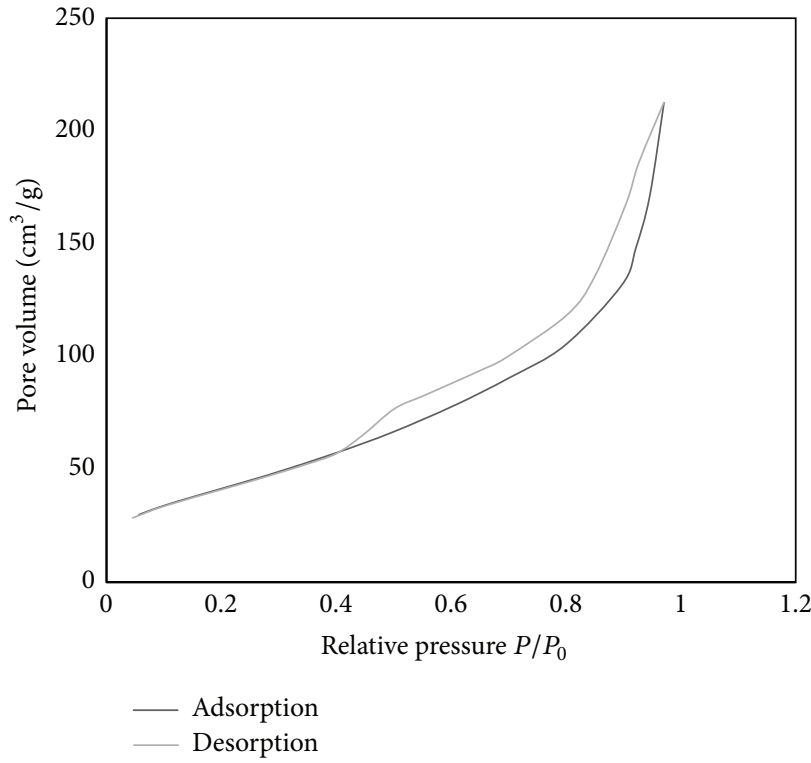

(a)

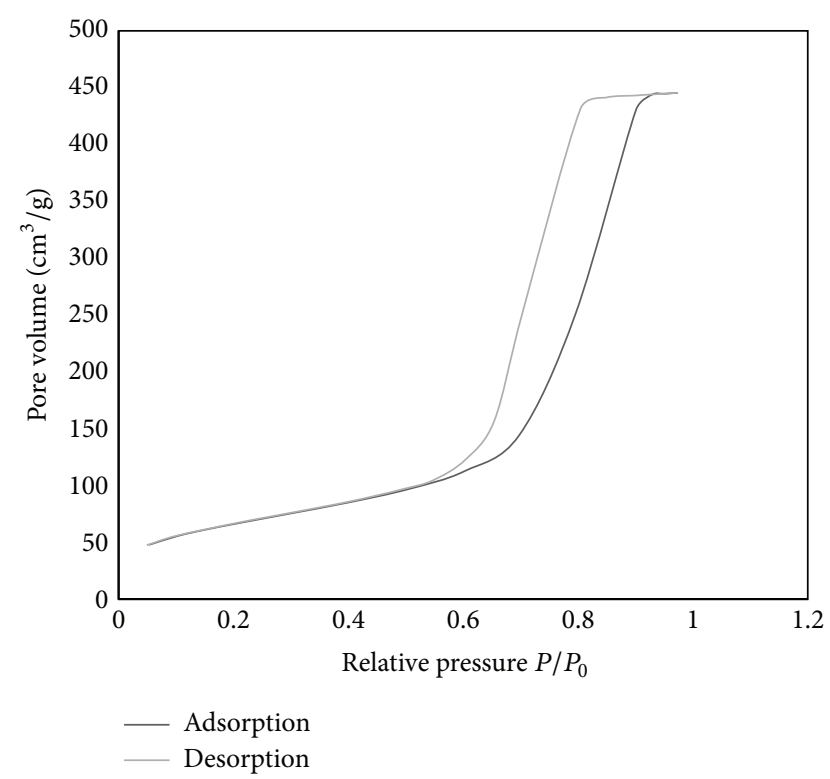

(b)

FIGURE 1: $\mathrm{N}_{2}$ adsorption/desorption isotherm of (a) florisil and (b) silica.

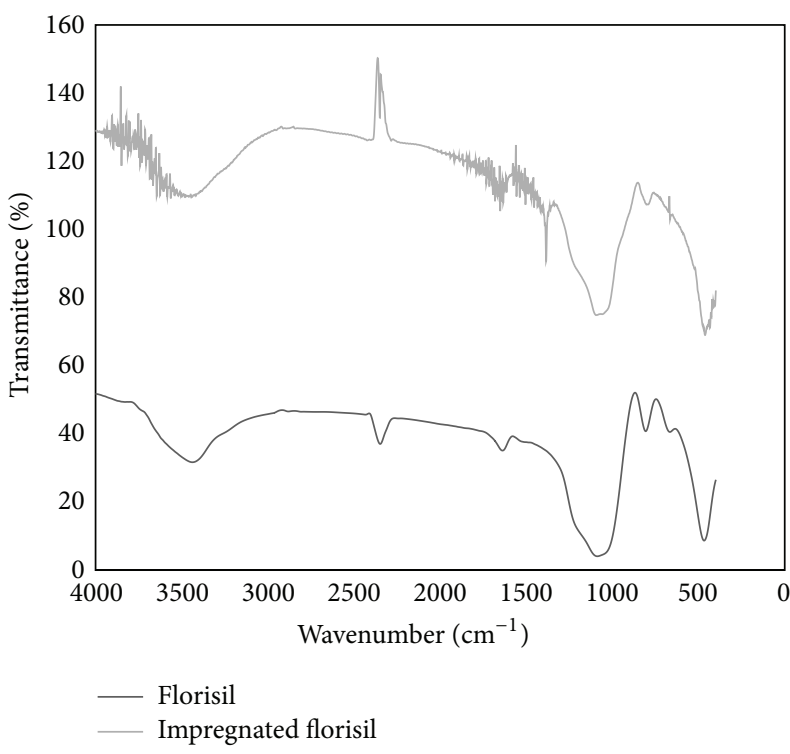

(a)

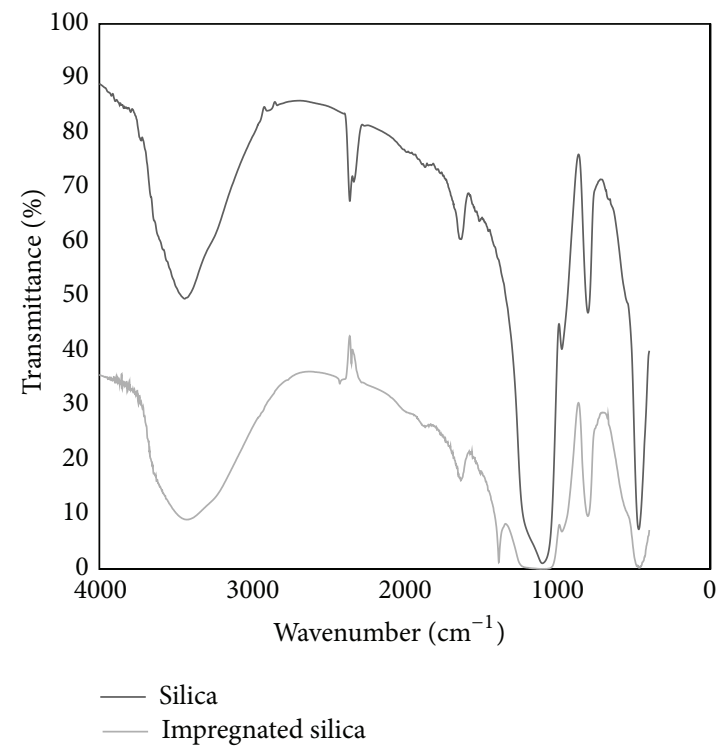

(b)

FIGURE 2: IR vibrational spectrum of studied adsorbents material. (a) Florisil. (b) Silica.

than the florisil sample. For this reason, it is expected that the impregnated silica will develop a higher adsorption capacity in the removal process of $\mathrm{As}(\mathrm{V})$ from aqueous solutions.

The florisil and silica impregnated with crown ether and $\mathrm{Fe}(\mathrm{III})$ ions were subjected to the FTIR analysis in order to prove that the impregnation occurred. The FTIR spectrum is provided in Figure 2. The intense bands around $1100 \mathrm{~cm}^{-1}$ are attributed to the $v_{\text {sym }}\left(\mathrm{C}_{\text {aliphatic }}-\mathrm{O}-\mathrm{C}_{\text {aromatic }}\right)$ and $v_{\text {sym }}\left(\mathrm{C}_{\text {aliphatic }}-\mathrm{O}-\mathrm{C}_{\text {aliphatic }}\right)$, respectively, which prove that the impregnation with dibenzo-18-crown-6 crown ether occurred $[26,27]$. In this interval, the adsorption bands are overlapped (between 1000 and $1200 \mathrm{~cm}^{-1}$ ) which are due to antisymmetric stretching mode and symmetric stretching mode of $\mathrm{Si}-\mathrm{O}-\mathrm{Si}$, respectively [11]. It is more obvious in case of the silica adsorbent. Figure 2 also has shown that the bending vibration bands of $\mathrm{CH}_{2}$ groups are presented at about $1460 \mathrm{~cm}^{-1}$ [28]. The FTIR spectrum shows a wider and higher peak at $3430 \mathrm{~cm}^{-1}$ in case of silica sample compared to florisil, revealing a higher content of $\mathrm{O}-\mathrm{H}$ bond, which come from a higher presence of $\mathrm{Fe}-\mathrm{OH}$ groups [7]. The IR spectrum confirms the fact that both studied solid supports were impregnated with crown ether and $\mathrm{Fe}(\mathrm{III})$ ions. In case 


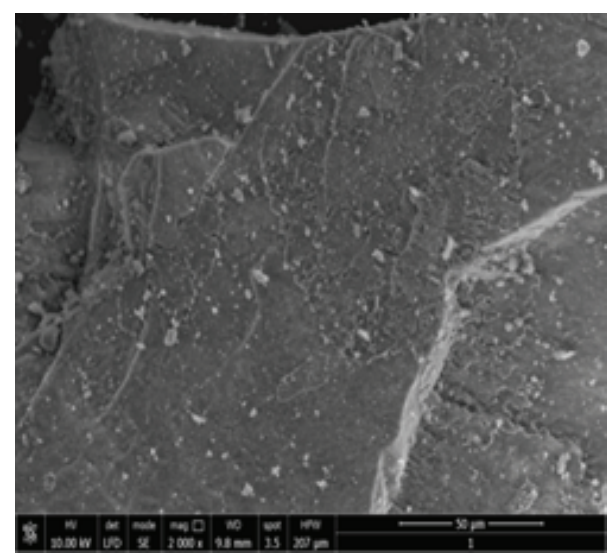

(a)

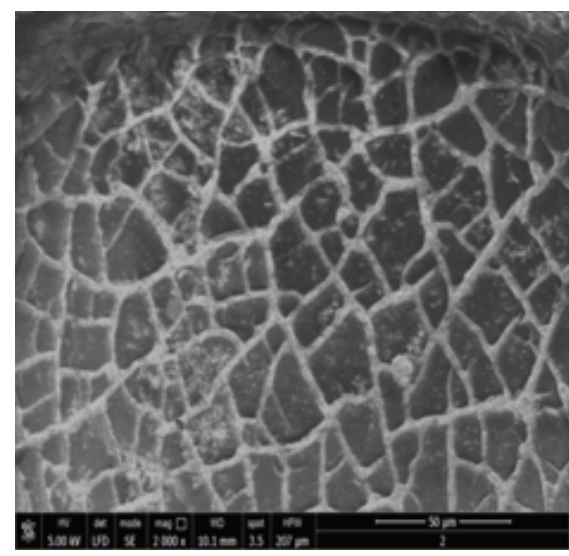

(b)

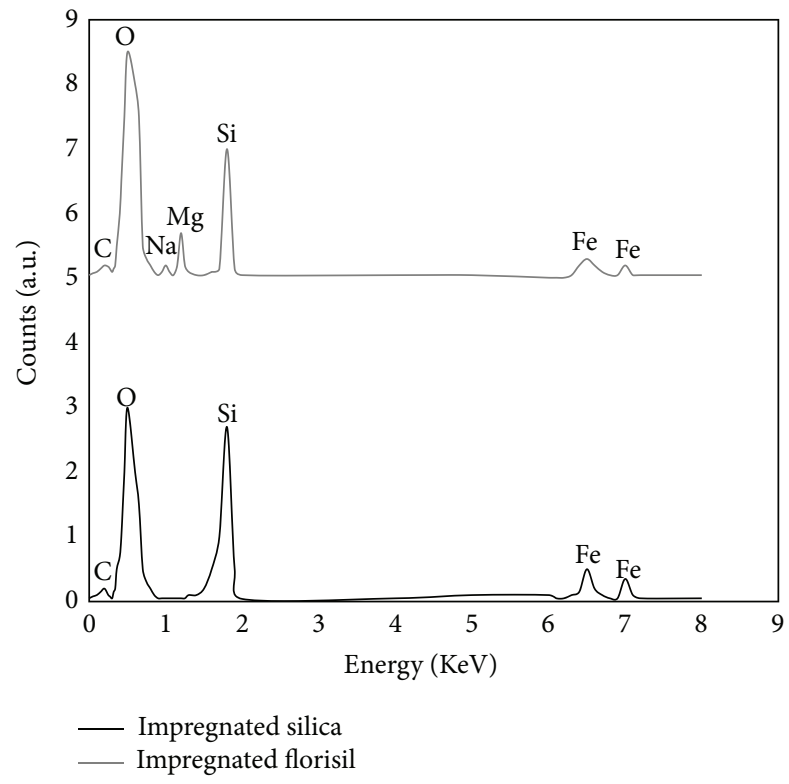

FIGURE 3: SEM images and EDX spectrum of impregnated florisil (a) and impregnated silica (b).

of silica, the impregnation process obviously suggests a higher quantity of crown ether and Fe(III) ions than in case of florisil. Therefore, the FTIR analysis suggests also that the impregnated silica is possible to develop a higher adsorption capacity.

The surface morphology and the EDX quantification of the obtained material are presented in Figure 3. The spherical shape of the micron sized silica particle presents a higher aggregation following surface treatment. Also it can be observed that the coating process with $\mathrm{Fe}(\mathrm{III})$ ions is inside the pore in case of silica rather than homogenous coating like in the case of florisil. The EDX quantification proved that the studied solid supports were impregnated with crown ether and loaded with $\mathrm{Fe}(\mathrm{III})$ ions.

\subsection{As $(V)$ Adsorption}

3.2.1. Influence of the $S: L$ Ratio on the Adsorption of $A s(V)$. Figure 4 presents the dependence of the adsorption capacity on the removal of $\mathrm{As}(\mathrm{V})$ from aqueous solutions for impregnated silica and florisil versus the $S$ : $L$ ratio.

Increasing the amount of impregnated silica used for removing As(V) from aqueous solutions leads to decreasing of the adsorption capacity because the adsorption capacity is in relation to the amount of adsorbent used. In the same time, the removal degree of $\mathrm{As}(\mathrm{V})$ from aqueous solution is not influenced by the amount of impregnated silica used in the adsorption process. In contrast to silica, the adsorption capacity for florisil remains almost constant for the $S: L$ ratio used, but the $A s(V)$ removal degree increases with the increasing of the $S: L$ ratio. In order to obtain both higher adsorption capacity and higher removal degree, the optimal $\mathrm{S}: \mathrm{L}$ ratio used for future experiments is $0.1 \mathrm{~g}$ impregnated silica and $0.5 \mathrm{~g}$ impregnated florisil for $25 \mathrm{~mL}$ of $\mathrm{As}(\mathrm{V})$ aqueous solutions.

3.2.2. Kinetic Studies. For the kinetic studies, the influences of the contact time on the adsorption capacity of the 
TABLE 2: Kinetic parameters for As(V) adsorption onto studied material.

\begin{tabular}{|c|c|c|c|c|c|c|c|}
\hline \multirow[b]{2}{*}{$\begin{array}{l}\text { Temperature } \\
(\mathrm{K})\end{array}$} & \multirow[b]{2}{*}{$\begin{array}{c}q_{\exp } \\
(\mu \mathrm{g} / \mathrm{g})\end{array}$} & \multicolumn{3}{|c|}{ Pseudo-first-order } & \multicolumn{3}{|c|}{ Pseudo-second-order } \\
\hline & & $\begin{array}{c}k_{1} \\
(1 / \mathrm{min})\end{array}$ & $\begin{array}{c}q_{\text {calc }} \\
(\mu \mathrm{g} / \mathrm{g})\end{array}$ & $R^{2}$ & $\begin{array}{c}k_{2} \\
(\mathrm{~g} / \mu \mathrm{g} \cdot \min )\end{array}$ & $\begin{array}{c}q_{\text {calc }} \\
(\mu \mathrm{g} / \mathrm{g})\end{array}$ & $R^{2}$ \\
\hline \multicolumn{8}{|c|}{ Impregnated silica } \\
\hline 298 & 17 & 0.0207 & 16.66 & 0.9730 & $1.195 \cdot 10^{-3}$ & 20.12 & 0.9919 \\
\hline 308 & 18.5 & 0.0141 & 11.25 & 0.9781 & $1.791 \cdot 10^{-3}$ & 20.20 & 0.9950 \\
\hline 318 & 19 & 0.0143 & 10.56 & 0.9895 & $2.225 \cdot 10^{-3}$ & 20.32 & 0.9978 \\
\hline \multicolumn{8}{|c|}{ Impregnated florisil } \\
\hline 298 & 2.5 & 0.0146 & 0.42 & 0.9887 & 0.077 & 2.53 & 0.9999 \\
\hline 308 & 2.6 & 0.0081 & 0.33 & 0.9614 & 0.083 & 2.59 & 0.9998 \\
\hline 318 & 2.7 & 0.0079 & 0.30 & 0.9634 & 0.090 & 2.69 & 0.9997 \\
\hline
\end{tabular}

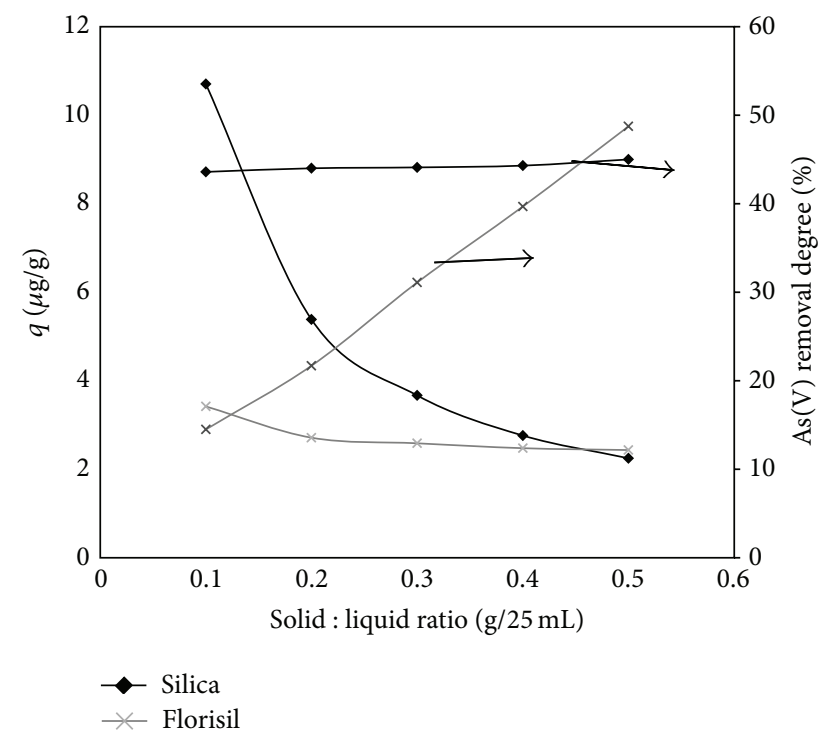

FIGURE 4: Influence of the S: L ratio on the removal of As(V) from aqueous solutions for impregnated silica and florisil.

impregnated silica and florisil were studied (Figure 5). The data showed that the adsorption capacity for both materials increases with increase of time till they reach the equilibrium at 180 minutes. The increase of the adsorption capacity with the time increasing in case of silica is very obvious; in case of florisil, this increase is not significant. The adsorption capacity of both of the studied materials increases with the temperature increasing indicating an endothermic nature of $\mathrm{As}(\mathrm{V})$ adsorption process.

The experimental data were fitted with the pseudo-firstorder (Figure 6) and the pseudo-second-order (Figure 7) kinetic models. The following equation defines the two kinetic models:

$$
\begin{aligned}
\ln \left(q_{e}-q_{t}\right) & =\ln q_{t}-k_{1} t, \\
\frac{t}{q_{t}} & =\frac{1}{k_{2} q_{e}^{2}}+\frac{t}{q_{e}},
\end{aligned}
$$

where $q_{e}$ and $q_{t}$ are the amount of adsorbate onto the adsorbent $(\mu \mathrm{g} / \mathrm{g})$ at equilibrium and at time $t$, respectively, $t$ is the contact time $(\mathrm{min}), k_{1}$ is the pseudo-first-order adsorption rate constant $\left(\mathrm{min}^{-1}\right)$, and $k_{2}$ is the pseudosecond-order adsorption rate constant (g/ $\mu \mathrm{g} \cdot \mathrm{min})$. The rate constant $k_{1}$ and the correlation coefficients were calculated from the slope and intercept of the linear representation of $\ln \left(q_{e}-q_{t}\right)$ versus $t$ (Figure 6) [29]. The rate constant $k_{2}$, the $q_{\text {calc }}$, and the corresponding linear regression coefficients were calculated from the linear plots of $t / q$ against $t$ (Figure 7) [30]. The values of constants, together with the regression coefficients $\left(R^{2}\right)$ obtained in all the cases, are summarized in Table 2.

The low correlation coefficients obtained for the pseudofirst-order kinetic model for impregnated silica and florisil as well as the difference between the experimental and the calculated adsorption coefficient show that it is not appropriate to fit the experimental data with this kinetic model. The values obtained for the pseudo-second-order kinetic model fit better the experimental data and represent the adsorption process of $\mathrm{As}(\mathrm{V})$ onto impregnated silica and florisil. Comparing the values for silica and florisil, it can be concluded that the adsorption process of $\mathrm{As}(\mathrm{V})$ on silica went much better than that on florisil.

To calculate the activation energy of the adsorption of $\mathrm{As}(\mathrm{V})$ on impregnated silica and florisil, the Arrhenius equation was used with the rate constant from the pseudosecond-order kinetic model:

$$
\ln k_{2}=\ln A-\frac{E}{R T}
$$

where $k_{2}$ is the pseudo-second-order rate constant of sorption $(\mathrm{g} / \mathrm{min} \cdot \mu \mathrm{g}), A$ is the Arrhenius constant which is a temperature independent factor $(\mathrm{min} \cdot \mathrm{g} / \mu \mathrm{g}), E$ is the activation energy of sorption $(\mathrm{kJ} / \mathrm{mol})$, and $T$ is the absolute temperature $(\mathrm{K})$. The activation energies were calculated from the slope of the plots of $\ln k_{2}$ versus $1 / T$ (Figure 8).

The activation energy calculated was $24.77 \mathrm{~kJ} / \mathrm{mol}$ for impregnated silica and $1.118 \mathrm{~kJ} / \mathrm{mol}$ for impregnated florisil. These values suggest that the adsorption of $\mathrm{As}(\mathrm{V})$ onto impregnated silica is a chemical sorption in comparison to the adsorption process onto impregnated florisil that is a physisorption. These conclusions suggest also that the impregnated silica could develop a higher maximum 


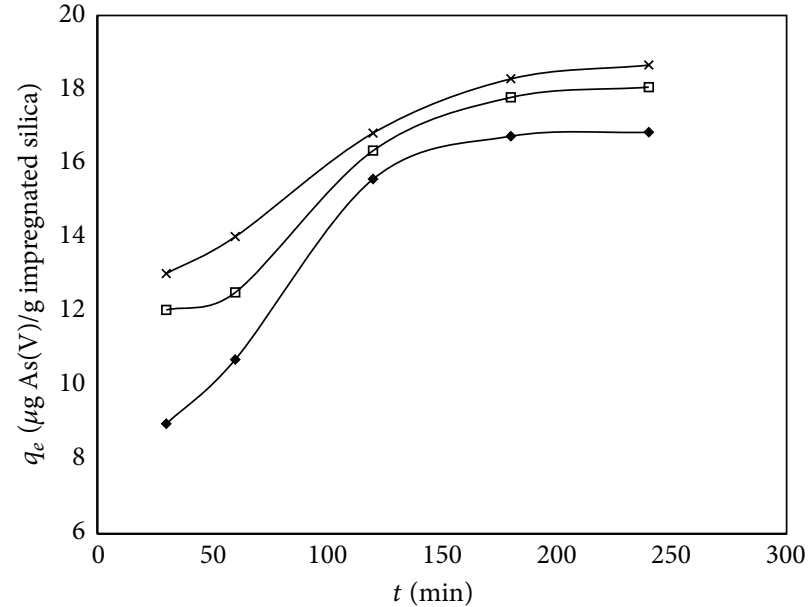

$\smile 298 \mathrm{~K}$

$\square-308 \mathrm{~K}$

$* 318 \mathrm{~K}$

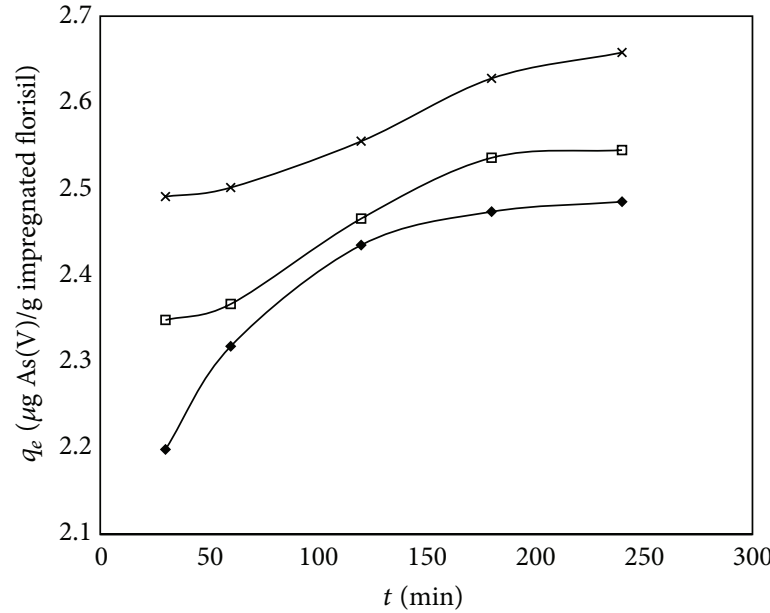

$\smile 298 \mathrm{~K}$

曰 $308 \mathrm{~K}$

$\leftarrow 318 \mathrm{~K}$

(a)

(b)

FIGURE 5: Influence of the contact time on the adsorption capacity of the impregnated silica (a) and on the impregnated florisil (b).

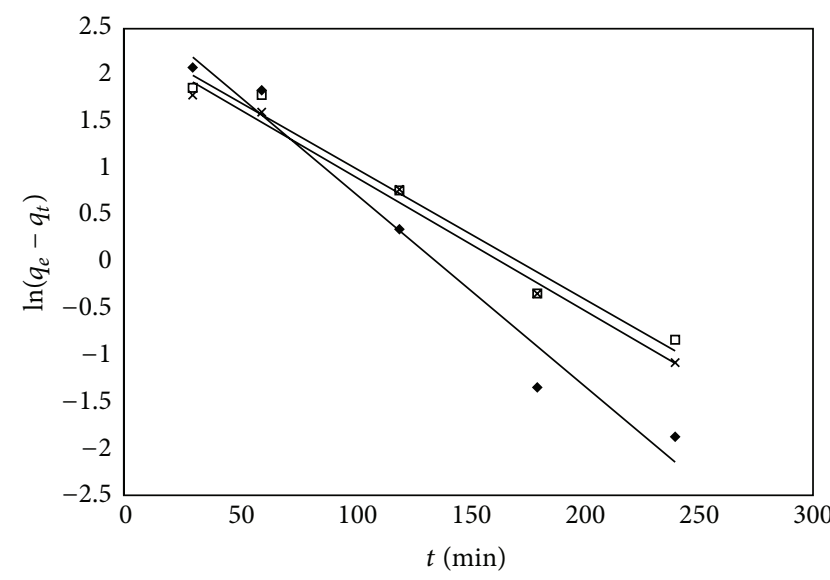

- $298 \mathrm{~K}$

$308 \mathrm{~K}$

$\times 318 \mathrm{~K}$

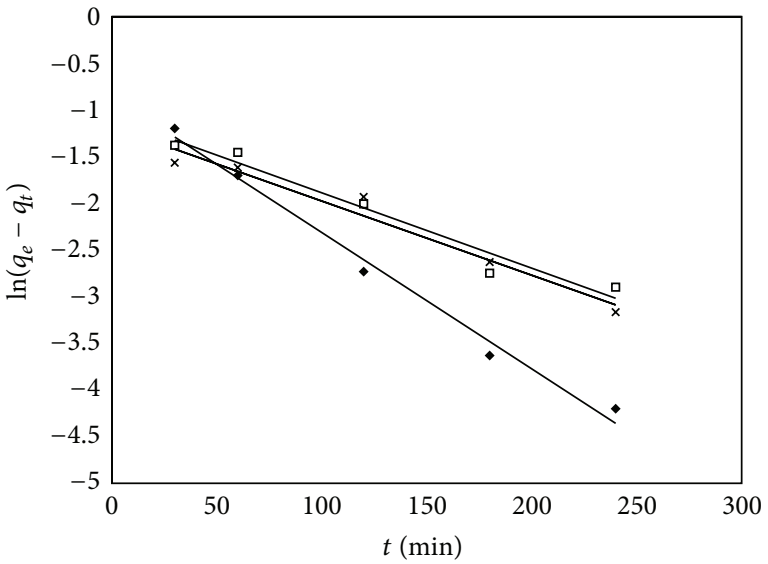

- $298 \mathrm{~K}$

- $308 \mathrm{~K}$

$\times 318 \mathrm{~K}$

(a)

(b)

FIgURE 6: Pseudo-first-order kinetic plots for silica (a) and florisil (b) at the adsorption of As(V).

adsorption capacity than the impregnated florisil in the removal process of $\mathrm{As}(\mathrm{V})$ from aqueous solutions.

3.2.3. Thermodynamic Studies. The thermodynamic studies were made to illustrate whether the adsorption process is a spontaneous process or not. Therefore, the equilibrium constant $K_{c}$ is defined as follows [31]:

$$
K_{c}=\frac{C_{A}}{C_{c}}
$$

where $C_{A}$ is the solid phase concentration at equilibrium $(\mu \mathrm{g} / \mathrm{L}), C_{c}$ is the equilibrium concentration $(\mu \mathrm{g} / \mathrm{L}), T(\mathrm{~K})$ is the absolute temperature, and $R$ is the gas constant.

If the equilibrium constant changing with the temperature is used, thermodynamic parameter such as the free energy change $\Delta G^{\circ}$, enthalpy change $\Delta H^{\circ}$, and entropy change $\Delta S^{\circ}$ can be estimated by

$$
\Delta G^{\circ}=-R T \ln K_{c},
$$

where $K_{c}$ is the equilibrium constant, $T(\mathrm{~K})$ is the absolute temperature, and $R$ is the gas constant. 


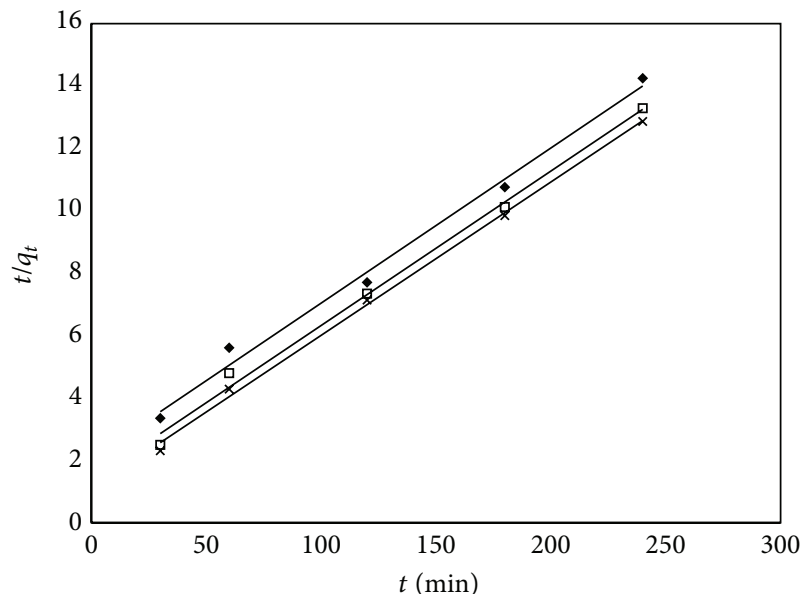

- $298 \mathrm{~K}$

- $308 \mathrm{~K}$

$\times 318 \mathrm{~K}$

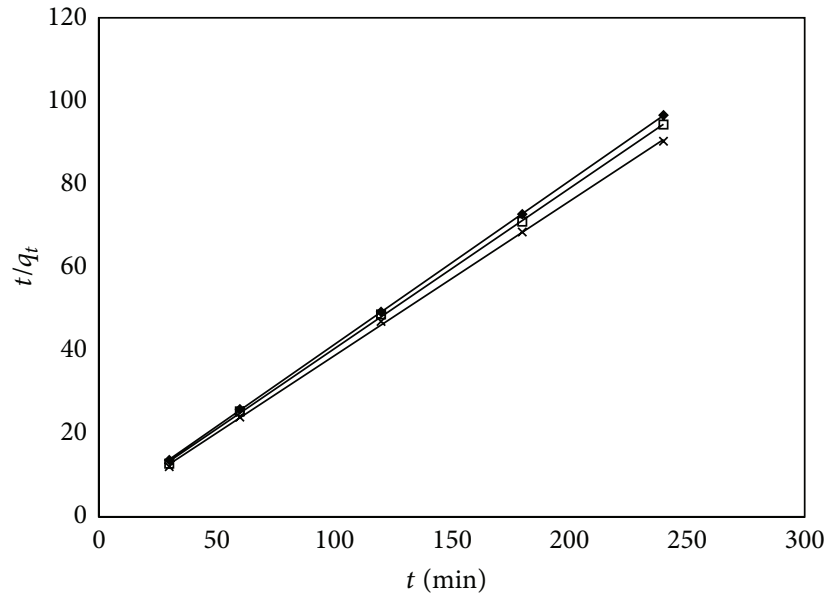

- $298 \mathrm{~K}$

- $308 \mathrm{~K}$

$\times 318 \mathrm{~K}$

(a)

(b)

FIgURe 7: Pseudo-second-order kinetic plots for silica (a) and florisil (b) at the adsorption of As(V).

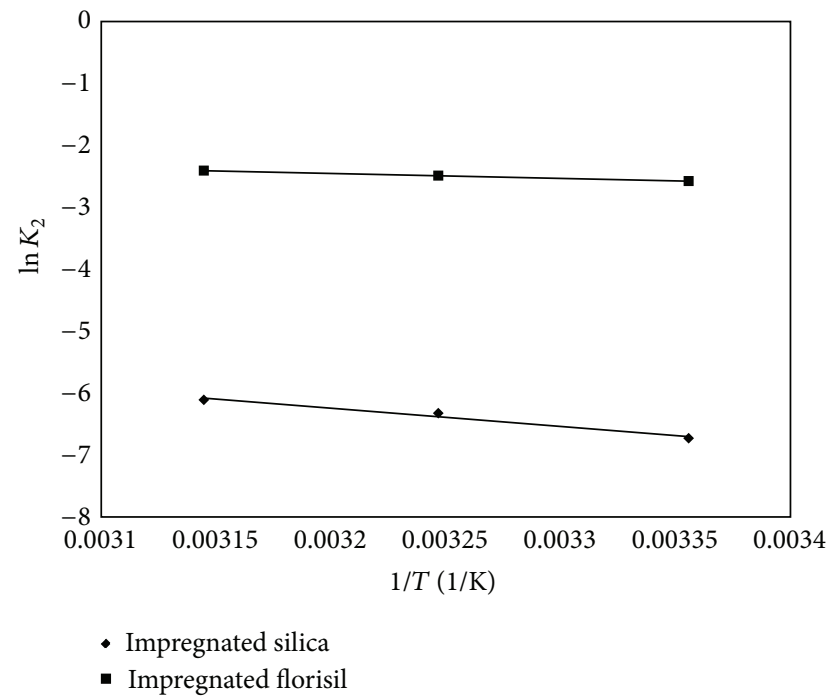

Figure 8: Arrhenius plot of $\mathrm{As}(\mathrm{V})$ adsorption onto impregnated silica and florisil.

The relations between the thermodynamic parameters are as follows:

$$
\begin{aligned}
\Delta G^{\circ} & =\Delta H^{\circ}-T \Delta S^{\circ} \\
\ln K_{c} & =\frac{\Delta S^{\circ}}{R}-\frac{\Delta H^{\circ}}{R T} .
\end{aligned}
$$

From the plot in $\ln K_{c}$ versus $1 / T$ (Figure 9), the values of $\Delta S^{\circ}$ can be determinate which are summarized in Table 3 .

All $\Delta G^{\circ}$ values are negative for silica which means that the adsorption process of $\mathrm{As}(\mathrm{V})$ is a spontaneous process. In case of impregnated florisil, the adsorption process is spontaneous only at higher temperature. For both studied materials, $\Delta G^{\circ}$

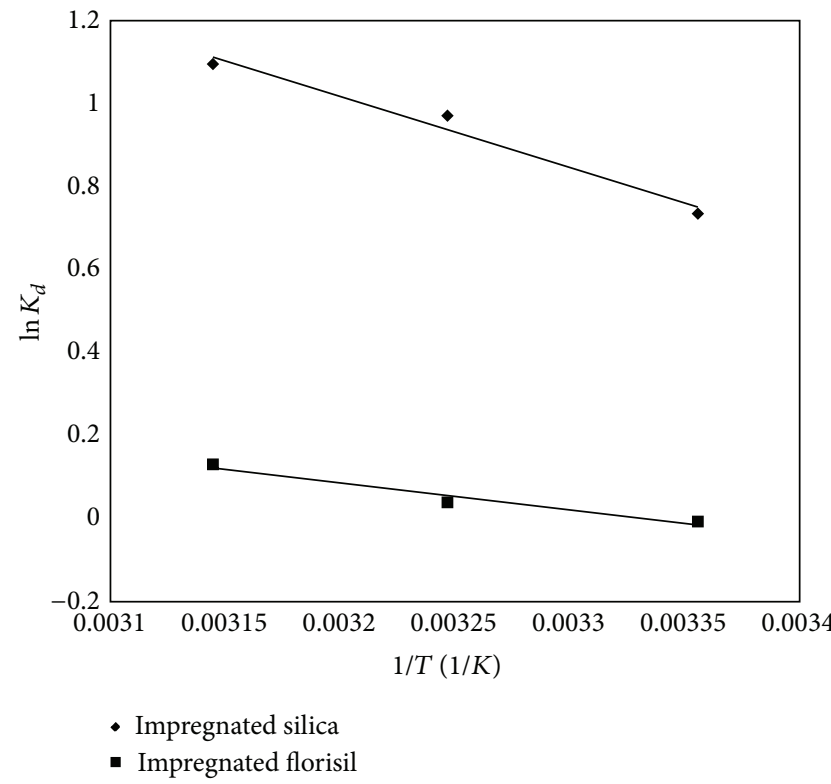

FIgURE 9: Temperature effect on the adsorption of $\mathrm{As}(\mathrm{V})$ onto impregnated silica and florisil.

decreases with increase of temperature. The adsorption of $\mathrm{As}(\mathrm{V})$ on the materials is an endothermic process due to the positive $\Delta H^{\circ}$ values obtained. The positive values of $\Delta S^{\circ}$ indicate an increased randomness at the solid-solution interface during the adsorption process [32].

3.2.4. Equilibrium Studies. The adsorption process of As(V) removal by impregnated silica and florisil is presented in Figure 10. 


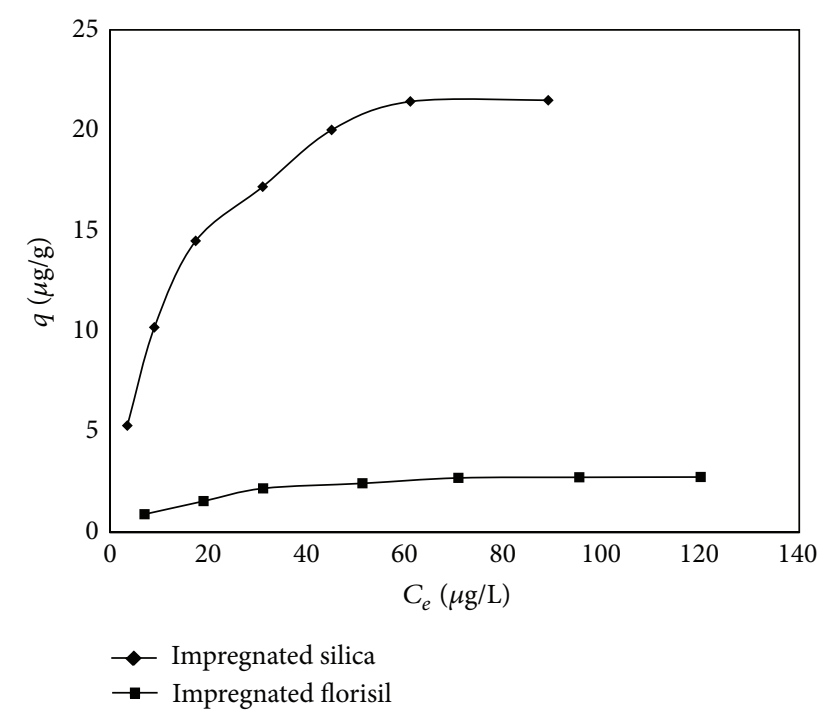

FIGURE 10: Adsorption isotherm of $\mathrm{As}(\mathrm{V})$ onto impregnated silica and florisil.

TABLE 3: Thermodynamic parameters.

\begin{tabular}{|c|c|c|c|c|c|c|}
\hline & \multirow{2}{*}{$\begin{array}{c}\Delta H^{\circ} \\
(\mathrm{kJ} / \mathrm{mol})\end{array}$} & \multirow{2}{*}{$\begin{array}{c}\Delta S^{\circ} \\
(\mathrm{J} / \mathrm{mol} \cdot \mathrm{K})\end{array}$} & \multicolumn{3}{|c|}{$\Delta G^{\circ}(\mathrm{kJ} / \mathrm{mol})$} & \multirow{2}{*}{$R^{2}$} \\
\hline & & & $298 \mathrm{~K}$ & $308 \mathrm{~K}$ & $318 \mathrm{~K}$ & \\
\hline Silica & 14.244 & 0.054 & -1.859 & -2.4 & -2.940 & 0.9752 \\
\hline Florisil & 5.417 & 18.05 & 0.03816 & -0.14234 & -0.32284 & 0.9577 \\
\hline
\end{tabular}

The adsorption capacity increases with the increase of the equilibrium concentration of $\mathrm{As}(\mathrm{V})$ onto the impregnated materials till it approaches a constant value at the highest equilibrium concentration. It can be noticed that the impregnated silica develops much higher adsorption capacity in the removal process of $\mathrm{As}(\mathrm{V})$ from aqueous solutions than the impregnated florisil. These results are in accordance with the conclusions raised from the characterization of the obtained materials and the conclusion raised from the activation energy.

To describe the equilibrium nature of the $\mathrm{As}(\mathrm{V})$ adsorption process onto impregnated silica and florisil, the Langmuir and Freundlich isotherm models were used.

The Langmuir isotherm can be expressed in linear form

$$
\frac{C_{e}}{q_{e}}=\frac{1}{K_{L} q_{m}}+\frac{C_{e}}{q_{m}},
$$

where $q_{e}$ is the amount of $\operatorname{As}(\mathrm{V})$ adsorbed per gram adsorbent, $q_{m}$ is the monomolecular adsorption capacity $(\mu \mathrm{g} / \mathrm{g}), C_{e}$ is the equilibrium concentration of the adsorbate in solution after the adsorption $(\mu \mathrm{g} / \mathrm{L})$, and $K_{L}$ is the Langmuir constant. From the linear plot of $C_{e} / q_{e}$ versus $C_{e}$, the values for $K_{L}$ and $q_{m}$ can be calculated (Figure 11) [8]. by

The Freundlich isotherm can be expressed in linear form

$$
\ln q_{e}=\ln K_{F}+\frac{1}{n} \ln C_{e},
$$

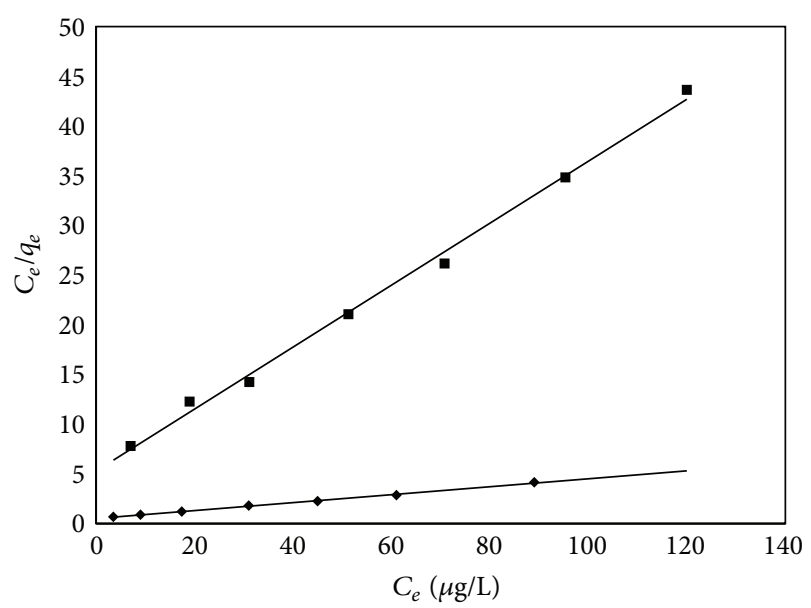

- Impregnated silica

- Impregnated florisil

FIGURE 11: Langmuir isotherm for As(V) adsorption on impregnated silica and florisil.

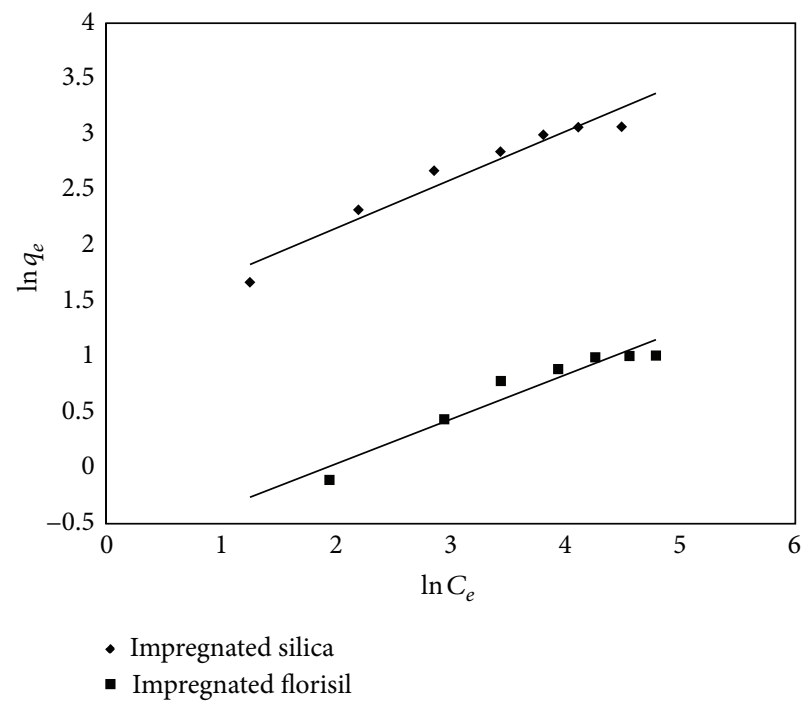

FIGURE 12: Freundlich isotherm for As(V) adsorption on impregnated silica and florisil.

where $q_{e}$ is the amount of $\operatorname{As}(\mathrm{V})$ adsorbed per gram adsorbent $(\mu \mathrm{g} / \mathrm{g}), C_{e}$ is the equilibrium concentration of the adsorbate in solution after the adsorption $(\mu \mathrm{g} / \mathrm{L})$, and $K_{F}$ is the Freundlich constant. $1 / n$ and $K_{F}$ can be determined by plotting $\ln q_{e}$ versus $\ln C_{e}$ (Figure 12).

Table 4 presents the parameters of Langmuir and Freundlich isotherms for the adsorption of $\mathrm{As}(\mathrm{V})$ onto impregnated silica and florisil.

Comparing the regression coefficient of the two isotherms, the Freundlich isotherm has a lower value than the Langmuir isotherm for both used materials. This suggests that the Langmuir model was more favorable, including the fact that a low difference between the $q_{m \text {,exp }}$ and $q_{m \text {,calc }}$ was observed. The Langmuir model describes an adsorption over a homogeneous surface and that all adsorption sites are 
Table 4: Parameters of Langmuir and Freundlich isotherms for the adsorption of As(V) onto impregnated silica and florisil.

\begin{tabular}{lcccccr}
\hline & $q_{m, \exp }$ & \multicolumn{3}{c}{ Langmuir isotherm } & \multicolumn{3}{c}{ Freundlich isotherm } \\
& $(\mu \mathrm{g} / \mathrm{g})$ & $K_{L}(\mathrm{~L} / \mu \mathrm{g})$ & $q_{m, \text { calc }}(\mu \mathrm{g} / \mathrm{g})$ & $R^{2}$ & $K_{F}(\mu \mathrm{g} / \mathrm{g})$ & $1 / n$ \\
\hline Silica & 21.5 & 0.078 & 25 & 0.9975 & 3.61 & 0.4355 \\
Florisil & 2.75 & 0.059 & 3.20 & 0.9959 & 0.47 & 0.9427 \\
\hline
\end{tabular}

energetically equivalent and do not affect the adsorption of molecules on an adjacent site $[6,33]$.

\section{Conclusions}

The present study showed that the adsorption efficiency of silica and florisil in the removal process of $\mathrm{As}(\mathrm{V})$ from aqueous solutions was increased by impregnation of the solid support with crown ether and loaded with Fe(III) ions. The obtained materials were characterized through SEM, EDX, BET, and FTIR analysis. The kinetic studies revealed that the adsorption process of $\mathrm{As}(\mathrm{V})$ onto the studied materials followed the pseudo-second-order kinetic model. The equilibrium data were fitted with Langmuir and Freundlich isotherm, the best correlation being obtained by the Langmuir one. The characterization analysis together with $\mathrm{As}(\mathrm{V})$ adsorption tests suggested that the impregnation process in case of silica solid support was more obvious than in case of florisil which leads to an excellent adsorption performance of $\mathrm{As}(\mathrm{V})$ when the silica solid support was used. The use of silica impregnated with crown ether and $\mathrm{Fe}(\mathrm{III})$ as adsorbent, in the removal process of As(V) from aqoueous solutions, represents an efficient method, because a good efficiency and selectivity of As(V) removal from aqueous solutions containing trace concentration is obtained. Also is achieved a residual concentration of $\mathrm{As}(\mathrm{V})$ under the maximum level admitted by the World Health Organization $(<10 \mathrm{ppb})$.

\section{Conflict of Interests}

The authors declare that there is no conflict of interests regarding the publication of this paper.

\section{References}

[1] D. van Halem, S. A. Bakker, G. L. Amy, and J. C. van Dijk, "Arsenic in drinking water: a worldwide water quality concern for water supply companies," Drinking Water Engineering and Science, vol. 2, no. 1, pp. 29-34, 2009.

[2] A. Mukherjee, M. K. Sengupta, M. A. Hossain et al., "Arsenic contamination in groundwater: a global perspective with emphasis on the Asian scenario," Journal of Health, Population and Nutrition, vol. 24, no. 2, pp. 142-163, 2006.

[3] C. M. Iesan, C. Capat, F. Ruta, and I. Udrea, "Evaluation of a novel hybrid inorganic/organic polymer type material in the Arsenic removal process from drinking water," Water Research, vol. 42, no. 16, pp. 4327-4333, 2008.

[4] F. Makavipour and R. M. Pashley, "A study of ion adsorption onto surface functionalized silica particles," Chemical Engineering Journal, vol. 262, pp. 119-124, 2015.
[5] J. Hao, M.-J. Han, C. Wang, and X. Meng, "Enhanced removal of arsenite from water by a mesoporous hybrid material-Thiolfunctionalized silica coated activated alumina," Microporous and Mesoporous Materials, vol. 124, no. 1-3, pp. 1-7, 2009.

[6] H.-T. Fan, T. Sun, H.-B. Xu, Y.-J. Yang, Q. Tang, and Y. Sun, "Removal of arsenic(V) from aqueous solutions using 3-[2(2-aminoethylamino)ethylamino]propyl-trimethoxysilane functionalized silica gel adsorbent," Desalination, vol. 278, no. 1-3, pp. 238-243, 2011.

[7] Y. Glocheux, A. B. Albadarin, J. Galán et al., "Adsorption study using optimised 3D organised mesoporous silica coated with $\mathrm{Fe}$ and $\mathrm{Al}$ oxides for specific $\mathrm{As}(\mathrm{III})$ and $\mathrm{As}(\mathrm{V})$ removal from contaminated synthetic groundwater," Microporous and Mesoporous Materials, vol. 198, pp. 101-114, 2014.

[8] A. Negrea, M. Ciopec, L. Lupa et al., "Removal of AsV by FeIIIloaded XAD7 impregnated resin containing Di(2-ethylhexyl) phosphoric acid (DEHPA): equilibrium, kinetic, and thermodynamic modeling studies," Journal of Chemical and Engineering Data, vol. 56, no. 10, pp. 3830-3838, 2011.

[9] S. D. Alexandratos, C. L. Stine, R. A. Sachleben, and B. A. Moyer, "Immobilization of lithium-selective 14-crown-4 on crosslinked polymer supports," Polymer, vol. 46, no. 17, pp. 6347-6352, 2005.

[10] O. Duman and E. Ayranci, "Attachment of benzo-crown ethers onto activated carbon cloth to enhance the removal of chromium, cobalt and nickel ions from aqueous solutions by adsorption," Journal of Hazardous Materials, vol. 176, no. 1-3, pp. 231-238, 2010.

[11] P. K. Mohapatra, D. S. Lakshmi, A. Bhattacharyya, and V. K. Manchanda, "Evaluation of polymer inclusion membranes containing crown ethers for selective cesium separation from nuclear waste solution," Journal of Hazardous Materials, vol. 169, no. 1-3, pp. 472-479, 2009.

[12] M. Streat, K. Hellgardt, and N. L. R. Newton, "Hydrous ferric oxide as an adsorbent in water treatment: part 2. Adsorption studies," Process Safety and Environmental Protection, vol. 86, no. 1, pp. 11-20, 2008.

[13] K. Gupta and U. C. Ghosh, "Arsenic removal using hydrous nanostructure iron(III)-titanium(IV) binary mixed oxide from aqueous solution," Journal of Hazardous Materials, vol. 161, no. 2-3, pp. 884-892, 2009.

[14] R. Goswami, P. Deb, R. Thakur, K. P. Sarma, and A. Basumallick, "Removal of as(III) from aqueous solution using functionalized ultrafine iron oxide nanoparticles," Separation Science and Technology, vol. 46, no. 6, pp. 1017-1022, 2011.

[15] F. Li and N. Dongyang, "Iron-based inorganic mesoporous materials," Progress in Chemistry, vol. 26, no. 6, pp. 961-975, 2014.

[16] A. Negrea, L. Lupa, R. Lazau, M. Ciopec, O. Pop, and M. Motoc, "Adsorption properties of $\mathrm{Fe}_{2} \mathrm{O}_{3}$ and $\mathrm{Fe}_{2} \mathrm{O}_{3}: \mathrm{SiO}_{2}$ mixtures in the removal process of as(III) from underground waters," Revista de Chimie, vol. 64, no. 5, pp. 487-494, 2013.

[17] F. Li, D. Geng, and Q. Cao, "Adsorption of As(V) on aluminum-, iron-, and manganese-(oxyhydr)oxides: equilibrium and kinetics," Desalination and Water Treatment, 2014. 
[18] F. Li, "Layer-by-layer loading iron onto mesoporous silica surfaces: synthesis, characterization and application for As(V) removal," Microporous and Mesoporous Materials, vol. 171, pp. 139-146, 2013.

[19] T. Möller and P. Sylvester, "Effect of silica and $\mathrm{pH}$ on arsenic uptake by resin/iron oxide hybrid media," Water Research, vol. 42, no. 6-7, pp. 1760-1766, 2008.

[20] B. R. White, B. T. Stackhouse, and J. A. Holcombe, "Magnetic $\gamma$ - $\mathrm{Fe}_{2} \mathrm{O}_{3}$ nanoparticles coated with poly-l-cysteine for chelation of $\mathrm{As}(\mathrm{III}), \mathrm{Cu}(\mathrm{II}), \mathrm{Cd}(\mathrm{II}), \mathrm{Ni}(\mathrm{II}), \mathrm{Pb}(\mathrm{II})$ and $\mathrm{Zn}(\mathrm{II})$," Journal of Hazardous Materials, vol. 161, no. 2-3, pp. 848-853, 2009.

[21] S. Lowell and J. E. Shields, Powder Surface Area and Porosity, Springer, 3rd edition, 1991.

[22] F. Rouquerol, J. Rouquerol, and K. Sing, Adsorption by Powders and Porous Solids, Academic Press, San Diego, Calif, USA, 1999.

[23] "IUPAC Recommendations Pure Applied Chemistry," 1985.

[24] "Names and symbols of transfermium elements (IUPAC Recommendations 1994)," Pure and Applied Chemistry, vol. 66, no. 12, pp. 2419-2421, 1994.

[25] F. Li, H. Fu, J. Zhai, and Q. Li, "Synthesis of mesostructured ferric oxyhydroxides templated by alkyl surfactants: effect of $\mathrm{pH}, \mathrm{F}^{-}$and solvents, and their adsorption isotherms for $\mathrm{As}(\mathrm{V})$," Microporous and Mesoporous Materials, vol. 123, no. 1-3, pp. 177-184, 2009.

[26] M. R. Awual, M. A. Shenashen, T. Yaita, H. Shiwaku, and A. Jyo, "Efficient arsenic(V) removal from water by ligand exchange fibrous adsorbent," Water Research, vol. 46, no. 17, pp. 55415550, 2012.

[27] M. R. Awual, S. A. El-Safty, and A. Jyo, "Removal of trace $\operatorname{arsenic}(\mathrm{V})$ and phosphate from water by a highly selective ligand exchange adsorbent," Journal of Environmental Sciences, vol. 23, no. 12, pp. 1947-1954, 2011.

[28] R. Nie, X. Chang, Q. He, Z. Hu, and Z. Li, "Preparation of p-tert[(dimethylamino)methyl]-calix[4] arene functionalized aminopropylpolysiloxane resin for selective solid-phase extraction and preconcentration of metal ions," Journal of Hazardous Materials, vol. 169, no. 1-3, pp. 203-209, 2009.

[29] A. Negrea, A. Popa, M. Ciopec et al., "Phosphonium grafted styrene-divinylbenzene resins impregnated with iron(III) and crown ether for arsenic removal," Pure and Applied Chemistry, no. 86, pp. 1729-1740, 2014.

[30] Y. S. Ho and G. McKay, "Pseudo-second order model for sorption processes," Process Biochemistry, vol. 34, no. 5, pp. 451$465,1999$.

[31] U. Kumar, "Thermodynamics of the adsorption of Cd(II) from aqueous solution on NCRH cylinder," International Journal of Environmental Science and Development, vol. 2, no. 5, pp. 334336, 2011.

[32] A. Negrea, L. Lupa, M. Ciopec, and P. Negrea, "Silica impregnated with Cyphos IL-101 for $\mathrm{Cs}^{+}$adsorption," Environmental Engineering and Management Journal, no. 13, pp. 2005-2013, 2014.

[33] J. Hao, M.-J. Han, C. Wang, and X. Meng, "Enhanced removal of arsenite from water by a mesoporous hybrid material-thiolfunctionalized silica coated activated alumina," Microporous and Mesoporous Materials, vol. 124, no. 1-3, pp. 1-7, 2009. 

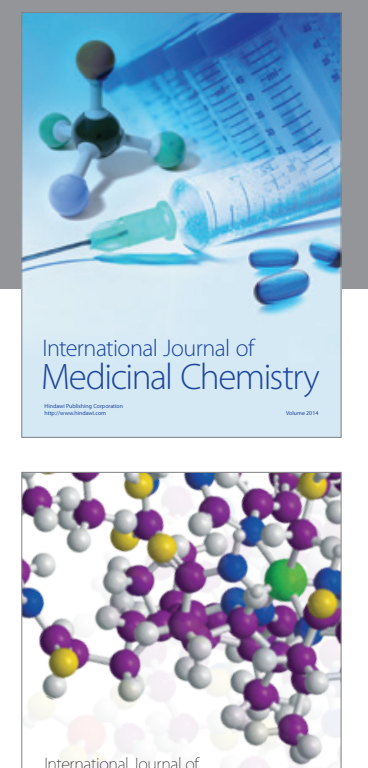

\section{Carbohydrate} Chemistry

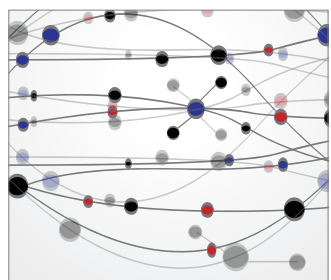

The Scientific World Journal
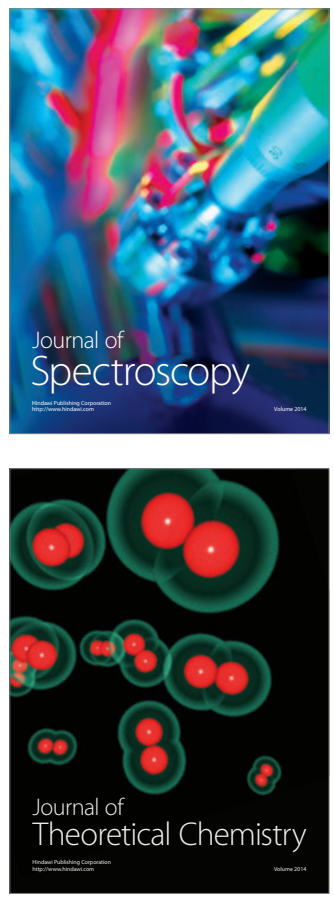
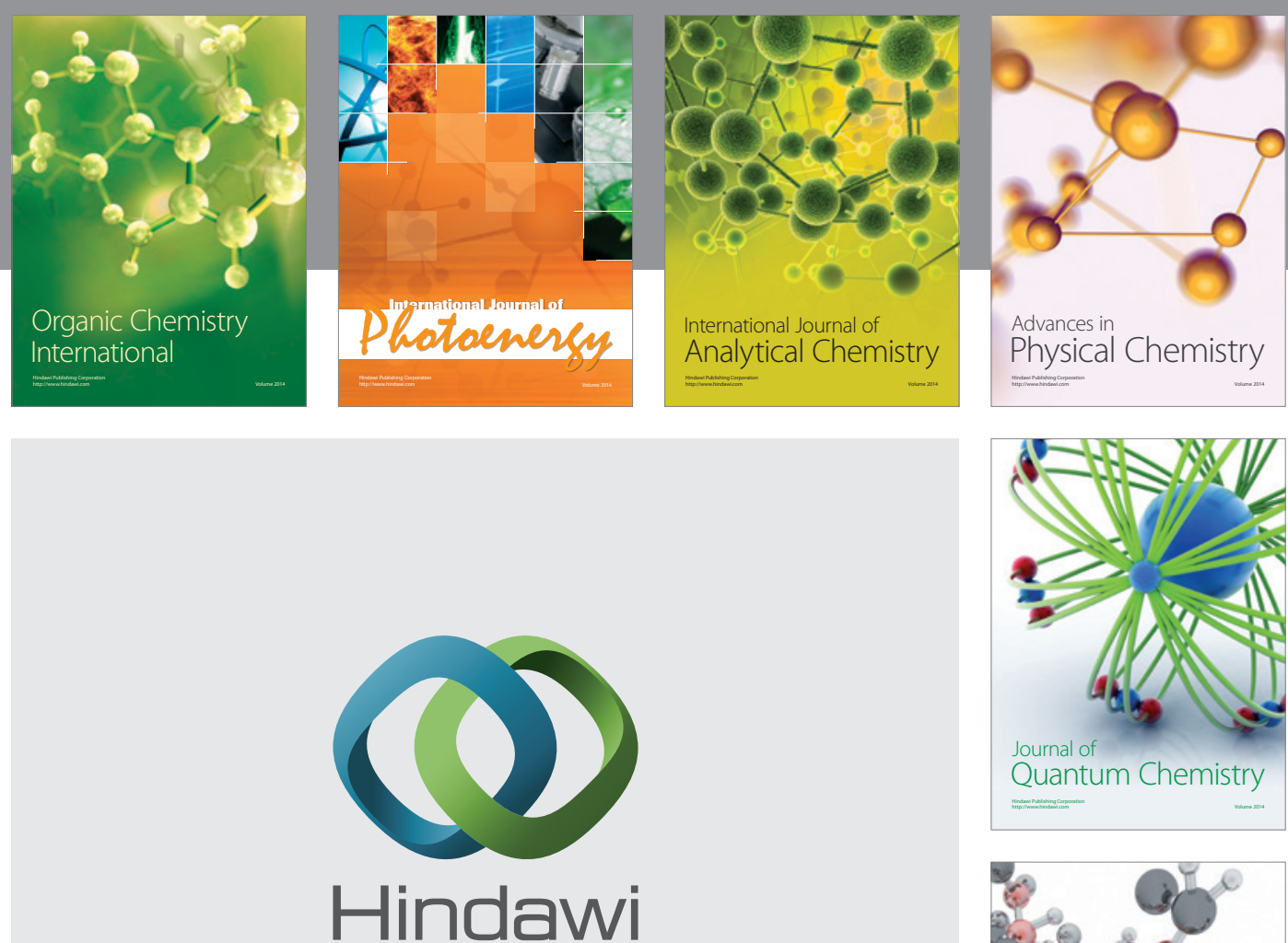

Submit your manuscripts at

http://www.hindawi.com

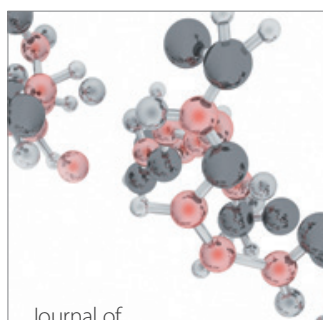

Analytical Methods

in Chemistry

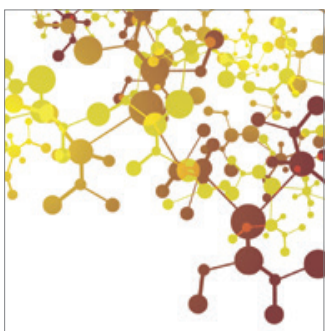

Journal of

Applied Chemistry

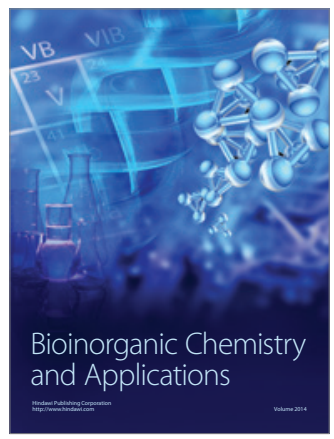

Inorganic Chemistry
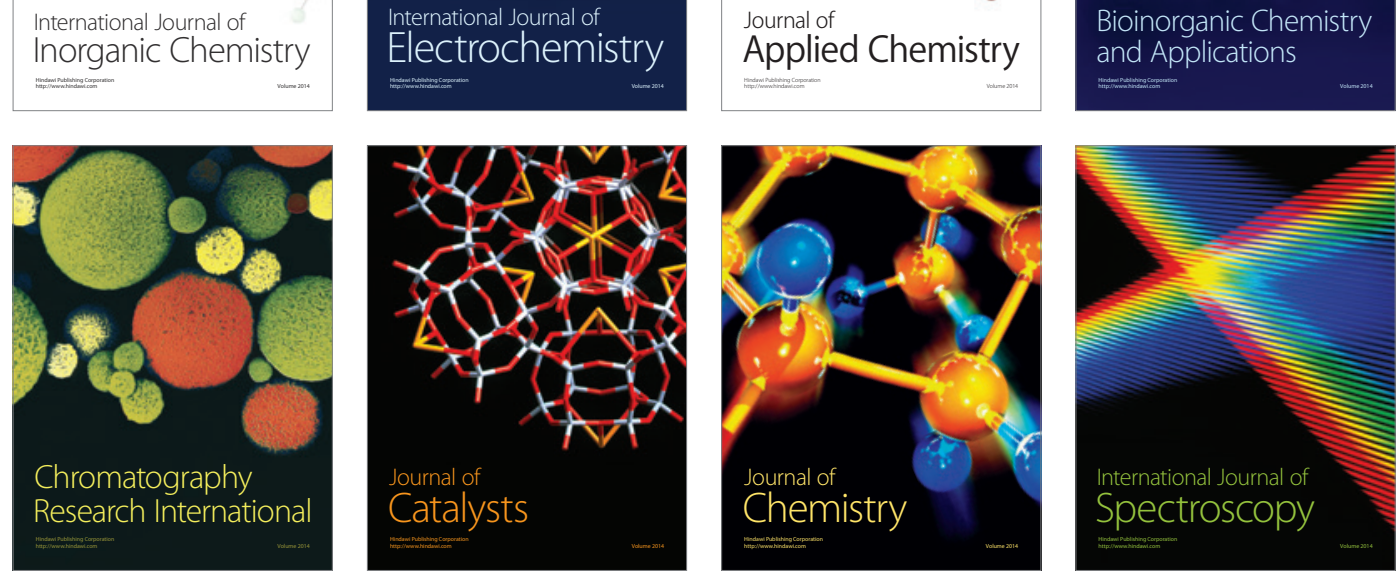